\title{
Constitutionalization of Socio-Economic Rights at THE EU LeVel: Some Critical Notes.
}

Orsola Razzolini ${ }^{1}$

\section{INTRODUCTION}

Frank I. Michelman raises four questions concerning the opportunity to include socioeconomic rights in a country's constitutional law. ${ }^{2}$ The first is a question of ideal political morality and an aspiration of justice in modern pluralist conditions. The second explores whether a commitment to socio-economic rights in constitutional law is a condition of minimum moral legitimacy that otherwise allows a state regime to require compliance by citizens with its statutory laws and policies. The third question concerns the need for a constitutional basis for socio-economic rights or legitimation-by-constitution. Finally, the fourth is a question of "judicialization", involving the competence of the country's courts of law to scrutinize "the adequacy of the state's performance in the field of social provisioning" and, in a broader sense, the legitimacy and adequacy of the state's economic policy, which scrutiny is usually deemed impossible in the United States. ${ }^{3}$

In Continental Europe, the Weimar Constitution of 1919 represents the first socioeconomic rights commitment in constitutional law. It reflects an attempt to reach a compromise between the individual liberalism of the $19^{\text {th }}$ century and the $20^{\text {th }}$ century aspiration of social justice and social solidarity that followed the rise of capitalism and collective movements and the shift away from a homogeneous (bourgeois) social structure toward a pluralist social structure. ${ }^{4}$

The idea of a "social-democratic constitution" reflects an abandonment of the laissezfaire approach for a new and different understanding of the relationship between state and economics, law, and politics. The state's interventionism in the socio-economic sphere, on the one hand, and the recognition of the normative power of collective autonomies (such as trade unions), on the other, are regarded as "social techniques" used to level socio-economic

\footnotetext{
${ }^{1}$ Associate professor of labour law, Ph.D. in Law of Business and Commerce (Bocconi), University of Genova, Law Department

${ }^{2}$ Frank Michelman "Legitimacy, the Social Turn, and Constitutional Review: What Political Liberalism Suggests," this volume, $\mathrm{X}-\mathrm{xx}$.

3 Id. at

${ }^{4}$ See, among others, KARL POLANYI, LA GRANDE TRASFORMAZIONE. LE ORGINI ECONOMICHE E POLITICHE DELLA NOSTRA EPOCA 210 (G. Einaudi ed., 2000; tit. or. The Great Transformation).
} 
inequalities, to achieve Sozialisierung. ${ }^{5}$ Within this framework, the constitutional catalogue of fundamental rights is enlarged to encompass social positive rights that, unlike liberal negative rights, create positive obligations for state action in the socio-economic sphere. ${ }^{6}$

Nevertheless, one of its main critiques concerned the excessive vagueness and uncertainty underpinning (a) the relationship between the state and its contractual partners which permitted a degeneration into Nazism - and (b) the catalogue of fundamental rights. ${ }^{7}$ Notably, fundamental social rights were understood more as "programmatic" principles or guidelines rather than directly-enforceable rights. ${ }^{8}$ They enabled courts of law to undertake constitutional interpretation and "social scrutiny" of economic policies and liberal rights; however, they were deprived of real effectiveness and justiciability, being rather dependent on legislative implementation.

The Weimar experience influenced all continental European constitutions that contain distinctions between liberal negative rights and social positive rights and between selfexecuting rights and rights whose enforceability depends on legislative implementation and state intervention. ${ }^{9}$ However, it is possible to find "bidirectional rights" 10 - that is to say, rights which combine negative and positive aspects - by creating both negative and positive obligations for the State. The most relevant in Italy, for example, are the freedom of organization (Article 39.1 of the Italian Constitution) and the right to strike (Article 40 of the Italian Constitution). The State obligation is, first, an obligation of non-interference with

\footnotetext{
5 GAETANO VARDARO, Il diritto del lavoro nel "laboratorio di Weimar", in ID., ITINERARI, 23 (Franco Angeli ed., 1989).

${ }^{6}$ Gerhard A. Ritter, Storia dello Stato Sociale, 111 (L. Gaeta \& P. Carnevale., 1996) (or Gerahard A. RITTER, DER SOZIALSTAAT. ENTSTEHUNG UND ENTWICKLUNG IM INTERNATIONALEM VERGLEICH (R.

Oldenbourg Verlag 1991). Traditionally, legal scholars distinguish liberal rights, which require the State not to interfere with the private sphere and autonomy, an expression of the Rechtstaat, and social rights, which require the active intervention of the State in the socio-economic sphere as to reestablish substantial equality and freedom, expression of the Social State. For this distinction, see, among others, ANTONIO BALDASSARRE, DIRITTI DELLA PERSONA E VALORI COSTITUZIONALE 122 (G. Giappichelli ed., 1997); L. Mengoni, I diritti sociali, ARGOMENTI DI DIRITTO DEL LAVORO, 1998, at 1; Olivier De Schutter, La garanzia dei diritti e principi sociali nella "Carta dei diritti fondamentali", in DIRITTI E COSTITUZIONE NELL'UNIONE EUROPEA 192 (G. Zagrebelsky ed., 2003).

7his is the idea of "contractual democracy" based on a permanent negotiation between the State and its contractual partners (business undertakings and Trade Unions). See, among others, HEINRICH A. WINCKLER, LA REPUBBLICA DI WEIMAR. 1918-1933: STORIA DELLA PRIMA DEMOCRAZIA TEDESCA, DONZELLI EDITORE (M. Sampaolo trans., 1998) (or. HEINRICH A. WINCKLER, WEIMAR 1918-1933. DIE GESCHICHTE DER ERSTEN DEUTSCHEN DEMOKRATIE (Verlag C.H. Beck 1993)).

${ }^{8}$ Id. See also, PIETRO BARCELlONA, DiRITTO PRIVATO E SOCIETÀ MODERNA 115 (Jovene Editore, 1996).

${ }^{9}$ See, among others, Baldassarre, supra note 6, at 175. See also, with regard to the CFR, Jeff Kenner, Economic and Social Rights in the EU Legal Order: the Mirage of Indivisibility, in ECONOMIC AND SOCIAL RIGHTS UNDER THE EU CHARTER OF FUNDAMENTAL RIGHTS - A LEGAL PERSPECTIVE at 3-4 (Jeff Kenner \& Thomas K. Hervery eds., 2002).

${ }^{10}$ Mengoni, supra note 6, at 7.
} 
these fundamental freedoms that are inherent in both the individual and the intermediate groups constituting a pluralist society. At the same time, the weight placed on the need to level socio-economic inequalities so as to achieve social justice, substantive equality, and "equal freedom" requires defined positive obligations for the state ${ }^{11}$ (as well as for the employer) and the introduction of rules intended to protect and promote effectiveness of these rights at both the national and workplace levels. ${ }^{12}$

The substantive indecisiveness and the compromise underlying the Weimar Constitution also characterizes the Charter of Fundamental Rights of the European Union (hereinafter, the "CFR" or "Charter"). The Charter contains a long catalogue of fundamental socio-economic rights listed in Chapter 4, significantly named "Solidarity". They include, for example: Worker's right to information and consultation within the undertaking (Article 27); Right of collective bargaining and action (Article 28); Right of access to placement services (Article 29); Protection in the event of unjustified dismissal (Article 30); Fair and just working conditions, without an express right to an equitable wage (Article 31); and Social security and social assistance (Article 34). Under Chapter 3, named "Equality", we find the right to nondiscrimination (Article 21), Equality between men and women (Article 23), and Integration of persons with disabilities (Article 26). In the Charter's Chapter 2, named "Freedoms", we find the Freedom to choose an occupation and the right to engage in work (Article 15).

For several scholars, the Charter's inclusion of the aforementioned socio-economic rights represents a 'constitutionalization of employment rights' at the EU level. ${ }^{13}$ But, what is here the meaning and the aim of the constitutionalization?

Following Michelman's lead, we might argue that the Charter's constitutional catalogue of fundamental socio-economic rights reflects the Union's aspiration of achieving social justice and harmonization between the economic and the social dimension. The socioeconomic rights commitment provides the Union with a minimum moral legitimation. In a communication on the CFR, the Commission underlines that the CFR is an "indispensable instrument of political and moral legitimacy". ${ }^{14}$

Notably, legitimation-by-constitution of socio-economic rights counterbalances the inclusion of fundamental economic freedoms in the Treaties, providing the Court of Justice

\footnotetext{
11 See supra note 9.

12 See the Italian Statute of Workers of 1970, Law no. 300.

13 See, among others, recently, Franck Lecompte, Embedding Employment Rights in Europe, COLUMBIA J. OF EUROPEAN LAW 17 (2011) 1; Marc Bell, Constitutionalization and EU Employment Law, University of Leicester School of Law Research, Paper No. 13-05, 1.

14 Brussels, 13.9.2000, COM (2000) 559 final, at 3.
} 
with the "constitutional legitimation" of its "social scrutiny" of institutional action and its judicial balancing of socio-economic rights and fundamental economic freedoms. ${ }^{15}$ The Court held, for instance, that the former are a legitimate limit on the latter ${ }^{16}$ or otherwise fell outside of the field of application of the applicable Treaty provision. ${ }^{17}$ More recently, the Court of Justice continued along the same path, regarding fundamental social rights that have a constitutional basis as a legitimate limitation of economic freedoms. ${ }^{18}$ However, as mentioned later, such limitations must be understood within the confines of the applicable Treaty provisions; they are, therefore, subject to intensive judicial scrutiny, in particular, the Court's "legitimate aim" and "proportionality tests. ${ }^{19}$

The constitutional character of social rights should allow the Court to affirm the "direct primacy and effectiveness and binding force" ${ }^{, 20}$ as well as "the higher or supralegal ranking in the regulatory hierarchy of the Community legal order". ${ }^{21}$ Mark Bell links the meaning of "constitutionalization" to "processes that seek to entrench certain legal norms and to attribute them with a higher status". ${ }^{22}$ This conclusion can be invoked with regard to Treaty provisions with a "constitutional character", meaning primacy and direct effect. ${ }^{23}$

Yet, the legal status of socio-economic rights listed in the CFR is far different. In the Communication of the Commission on the CFR, it was made abundantly clear that "the Charter will not be a vehicle to extend or reduce the powers of the Union and the Community, as established by the Union Treaty and EC Treaty. The Charter is neutral with

\footnotetext{
15 Mengoni, supra note 6, at 5, where he observes that with the catalogue of social rights, the question of the social Welfare state turns out to be not a political question but a question of constitutional interpretation and balance of conflicting rights. This argument is underlined in Maria V. Ballestrero, Brevi osservazioni su Costituzione europea e diritto del lavoro italiano, LAV. DIR. 559 (2000).

${ }^{16}$ See De Schutter, supra note 6, at 210.

17 In Albany, C-67/96, EU:C:1999:430, the Court famously holds that collective agreements "concluded in the context of collective negotiations between management and labour, in pursuit of social policy objectives such as the improvement of conditions of work and employment, must, by virtue of their nature and purpose, be regarded as falling outside the scope of Article 85(1) of the Treaty", concerning competition law.

${ }^{18}$ See the landmark judgments The International Transport Workers' Federation and The Finnish Seamen's Union v. Viking Line, C-438/05, EU:C:2007:772; Laval un Partneri, C-341/05, EU:C:2007:809.

${ }^{19}$ See the critics developed by Brian Bercusson, The Lisbon Treaty and Social Europe, 10 ERA Forum (2009) 10) at 95 . According to Bercusson, the equal value of social rights and economic freedoms, contrary to some European constitutional tradition, depends on the advent of Article 6 of the Lisbon Treaty, that has substantially reduced the weight of the Charter from being of constitutional significance to being equated to other Treaty provisions.

${ }^{20}$ See Miguel Rodríguez-Piñero \& Emilia Casas, In Support of a European Social Constitution, in EUROPEAN COMMUNity LABOUR LAW: PRINCIPLES AND PERSPECTIVES. LIBER AMICORUM LORD WEDDERBURN OF ChARLton 23 (Paul Davies et al. eds., 1996).

${ }^{21}$ Id.

22 Marc Bell, supra note 13.

23 See Bruno De Witte, Direct Effect, Primacy and the Nature of Legal Order, in THE EVOLUTION OF EU LAW 323 (Paul Craig \& Gráinne De Búrca eds., 2011).
} 
regard to the division of powers. Changes in any powers would be a matter for the Intergovernmental Conference, not for the Convention." 24 One goal of the Charter is to control and limit action by the EU Institutions while neither setting forth policy objectives nor committing those same institutions to take any particular social action. In this respect, when explaining why the right to work and the right to an equitable wage have not been included, the Commission said that "they were seen as simply setting policy objectives, which the Cologne conclusions ${ }^{25}$ prevent from being included in the Charter". ${ }^{26}$

Thus, the constitutional character of the socio-economic rights set out in the Charter must be tempered by the fact that the Charter is neutral and neither affects the competences or powers of the Union and the Member States and their respective institutions nor establishes social policy objectives for them. The listed socio-economic rights do not, therefore, limit the sphere of the Single Market. ${ }^{27}$ This is, of course, a completely different approach from the one used in the Weimar Constitution, which intentionally set out to define a new relationship between the State and economy, its law and policy. Due to the lack of clarity with respect to the EU's commitment to socio-economic rights and further, its lack of competence with respect thereto, their so-called constitutionalization at the EU level seems far to be completed.

The meaning of constitutional character is even more problematic in front of the ambiguous distinction between rights and principles ${ }^{28}$ and then goes on to explicitly provide that principles (but not rights)

may be implemented by legislative and executive acts taken by [EU institutions and Member States implementing EU law, which acts] shall be judicially cognisable only in the interpretation of such acts and in the ruling on their legality. ${ }^{29}$

Principles, unlike rights, only have only "normative justiciability" (justiciabilité normative), ${ }^{30}$ which conclusion raises several doubts about the existing relationship between principles

\footnotetext{
${ }^{24}$ Brussels, 13.9.2000, COM(2000) 559 final, at 5.

25 Conclusions of the Cologne European Council: extract concerning the Charter of Fundamental Rights (3 and 4 June 1999), available at http://www.cvce.eu/content/publication/2005/2/23/21760f35-0ad1-482f-bb9e1ba723c6ce19/publishable_en.pdf.

${ }^{26}$ Id. at 7.

${ }^{27}$ Ballestrero, supra note 15 , at 7.

28 Charter, Art. 51.1.

${ }^{29}$ Charter Art. 52.5.

${ }^{30}$ See Pierre Rodière, Les droits sociaux fondamentaux à l'épreuve de la constitution européenne, LA SEMAINE JURIDIQUE-EDITION GÉNÉRALE, 18 May 18, 2005, at I 136; Jean-François Akandji-Kombé, Droit
} 
included in the CFR and rights included in the European Convention on Human Rights (ECHR), which are, on the contrary, accorded direct horizontal effect.

Leaving aside such ambiguities and uncertainties, the constitutionalization of socioeconomic rights (and principles) opens up the possibility of investigating the role that the solidarity principle and socio-economic rights can play in the interpretation of the acts of Members States and EU institutions. In the next sections, I will first distinguish between "individual" employment rights (such as the right to non-discrimination and the right to paid annual leave) and "collective" employment rights (such as the right to information and consultation and the right to collective bargaining and action).

II. CONSTITUTIONALIZATION OF INDIVIDUAL EMPLOYMENT RIGHTS: THE RIGHT TO NON-DISCRIMINATION AND THE RIGHT TO PAID ANNUAL LEAVE

ECJ judgments concerning the right to non-discrimination and the right to paid annual leave are an excellent place to begin the analysis, starting from its first judgment in BECTU. ${ }^{31}$ In giving his opinion to the Court, AG Tizzano observed that the right to paid annual leaves is a fundamental, automatic, and unconditional right granted to every worker to whom the Charter assures full and effective implementation. ${ }^{32}$ In Pfeiffer, the ECJ held that the need to effectively protect the health and safety of workers implied that any derogation from minimum requirements or maximum limits - such as the 48 hour limit on the number of hours that can be worked in any 7 -day period ${ }^{33}$ - requires the express and free consent of the individual worker. ${ }^{34}$ Consent given by that worker's trade union representatives was not considered an equivalent. More precisely, it is necessary to ensure that

if the worker concerned is encouraged to relinquish a social right which has been directly conferred on him by the directive, he must do so freely and with full knowledge of all the facts. ${ }^{35}$

In $K H S,{ }^{36}$ the Grand Chamber of the CJEU confirmed that

the right to paid annual leave is, as a principle of European Union social law, not only particularly important ... but is also expressly laid down in Article

constitutionnel, droit international et droit européen des droit de l'homme : concurrance, confusion,

complémentarité ?, DROIT SOCIAL, Apr. 14 2014, at 301.

31 BECTU, C-173/99, EU:C:2001:356.

32 AG Tizzano Opinion, BECTU, C-173/99, EU:C:2001:81, para. 27.

33 As calculated pursuant to Article 16.2 of Directive 93/104.

34 Pfeiffer and Others, C-397/01 to C-403/01, EU:C:2004:584.

35 Ibid., para. 82.

${ }^{36}$ KHS, C-214/10, EU:C:2011:761. 
31(2) of the Charter of Fundamental Rights of the European Union, which Article 6(1) TEU recognizes as having the same legal value as the Treaties. ${ }^{37}$

In Dominguez, ${ }^{38}$ the Court underscored that the right to paid annual leave is a fundamental right provided with direct effect, given that the wording of Article 7(1) of the Directive 2003/88/EC is unconditional and sufficiently precise, depending, however, on the public or private nature of the body or organization against which the individual is making his or her claim.

Examples of constitutionalization of individual employment rights are particularly prevalent in CJEU judgments addressing equality law. In the famous Mangold case, ${ }^{39}$ the Court drew a distinction between the effects of ordinary EU law and the effects of EU law that expresses fundamental rights. Generally, the principle of age equality in employment obligates national courts, who are called upon to guarantee the principle's full effectiveness, to set

aside any provision of national law which may conflict with Community law, even where the period prescribed for transposition of that directive has not yet expired. $^{40}$

In another leading case, Kücükdeveci, ${ }^{41}$ the Court of Justice went even further, holding that the need to ensure full effectiveness of the principle of non-discrimination on the ground of age (as expressed in Dir. 2000/78) requires national courts to decline to apply national provisions considered to be incompatible with that principle, thereby overcoming the limits of the vertical effect of Directives provided with direct horizontal effect.

As has been observed, in terms of legal effect, the Kücükdeveci approach:

seems to epitomise the idea of constitutionalization; certain legal instruments would be granted an elevated legal status based on their connection to the protection of fundamental rights. ${ }^{42}$

The special combination of the Directive (Dir. 2000/78/EC) and the fundamental right to nondiscrimination on the ground of age (Article $21 \mathrm{CFR}$ ) allowed the Court to give the Directive direct horizontal effect.

\footnotetext{
${ }^{37}$ KHS, C-214/10, EU:C:2011:761, para. 37.

38 Dominguez, C-282/10, EU:C:2012:33.

${ }^{39}$ Mangold, C-144/04, EU:C:2005:709.

${ }^{40}$ Mangold, C-144/04, EU:C:2005:709, para. 78.

${ }^{41}$ Kücükdeveci, C-555/07, EU:C:2010:21.

${ }^{42}$ Bell, supra note 13 , at 20.
} 
What is missing in both Mangold and Kücükdeveci is the underlying legal reasoning that justifies giving direct horizontal effect to the principle of non-discrimination on the ground of age. ${ }^{43}$ By retracing the judgments, however, a possible reason seems to lie in the Court's finding that such principle is a "general principle of Community Law", ${ }^{44}$ which should permit its recognition as a subjective right afforded direct enforceability by Article 52.4 of the Charter. That provision specifically recognizes "fundamental rights as they result from the constitutional traditions common to the Member States". A second argument can be found in the Court's finding that Directive 2000/78/EC gives specific content and expression to the principle. ${ }^{45}$ Yet another explanation relies on Article 6 of the Lisbon Treaty, which equates fundamental rights to Treaty provisions, giving both primacy and direct effect. Finally, another reason lies in an innovative, broad interpretation of the duty of fair cooperation of national courts, bound by the principle of effet utile.

Neither Mangold nor Kücükdeveci provide a clear answer to the following question: In light of the Charter's distinction between rights and principles in its Article 51 is the right to non-discrimination, set forth in its Article 21 a right or a principle? If Article 52.4 seems to indicate the possibility of aligning rights that result from the constitutional tradition common to Member States with subjective fundamental rights, in Kücükdeveci, the Court seems to equate the right to non-discrimination on the ground of age with a principle to which Directive 2000/78/EC has given substantive content and expression. The principle, as implemented by the Directive, can be invoked by private citizens, obligating national courts to assess the compatibility of national law with EU law and to set aside national legislation if it is found to undermine the effectiveness of that principle. A national judge must not only interpret national legislation so as to comply with EU law, but must also decline to apply such national legislation when it does not comply with a Directive that gives substantive content and expression to the fundamental principle of non-discrimination.

Within this framework, the principle of non-discrimination is provided with both direct and indirect horizontal effect, regardless the public or private nature of the body or organization against which the individual is making his claim. ${ }^{46}$ To some extent, this

\footnotetext{
${ }^{43}$ See, critically, Mirjam de Mol, Kücükdeveci: Mangold Revisited - Horizontal Direct Effect of a General Principle of EU Law: Court of Justice of the European Union (Grand Chamber) Judgment of 19 January 2010, Case C-555/07, Seda Kücükdeveci v. Swedex GmbH \& Co. KG, 293 EUR. CONST. L. REV. (2010).

${ }^{44}$ Mangold, C-144/04, EU:C:2005:709, para. 75; Kücükdeveci, C-555/07, EU:C:2010:21, para 21.

45 Kücükdeveci, C-555/07, EU:C:2010:21, para. 21.

46 In this respect, Kücükdeveci goes beyond Dominguez and also, as we shall see in section 3, Association de Médiation Sociale. In Domiguez the Court affirms that the special combination between the fundamental right to annual paid leave and the wording of Article 7(1) of the Working Time Directive, that are unconditional and
} 
approach recalls the French and Italian idea of indisponibilite de la qualification - that is, the idea that certain employment protections are given "constitutional" legal status and primacy over legislation, based on their connection to constitutional rights ${ }^{47}$-or, with appropriate distinctions, the German Schutzpflicht (i.e., duty to protect) jurisprudence that is sometimes linked to the horizontal Mittelbare Drittwirkung theory; ${ }^{48}$ national judges are bound to give full effect in private relations to fundamental principles governing the EU legal order.

Finally, it is worth noting that the principle of non-discrimination is understood as a socio-economic principle, combining both social and economic objectives. ${ }^{49}$ The principle of non-discrimination serves both market integration (non-discrimination has always been the principal tool for achieving the Single Market) and social justice (e.g., the rationale behind the introduction of affirmative actions, the weight placed on the protection of human dignity, the codification of the duty of reasonable accommodation in case of disability, and mainstreaming policies). ${ }^{50}$

Yet, in the aforementioned judgments, the principle of non-discrimination is understood only in its individual dimension. The collective dimension of the principle (which certainly exists when one considers mainstreaming policies, the role played by social dialogue, and the

sufficiently precise, allow to provide the principle with direct horizontal effect, but only if the body or organization the individual is acting against has a public nature.

${ }^{47}$ For the academic debate, see Antoine Jeammaud, L'avenir sauvegardé de la qualification de contrat de travail: À propos de l'arrêt Labbane, DroIT SocIAL, Mar. 1 2001, at 229; Massimo D'Antona, Limiti costituzionali alla disponibilità del tipo contrattuale nel diritto del lavoro, ARGOMENTI DI DIRITTO DEL LAVORO, 1995, at 63. For French judgments, see Cour de cassation soc., Dec. 9 1970, Bull. Civ V, No. 703 (Fr.). More recently, see Cour de cassation soc., Dec. 19, 2000 (Arrêt Labbane), (2001) Droit Social, 237; Cour de cassation soc., June 15, 2005, Juris Classeur, No. 03-44-538; Cour de cassation soc., Dec. 10, 2008, Juris Classeur, No. 07-43.117; For Italian case law, see Corte Cost., Mar. 29, 1993, No. 121, (1993) Foro Italiano, I, 2432; Corte Cost., Mar. 31, 1994, No. 115, (1994) Foro italiano, I, 2656; Cass., Mar. 15, 2003, No. 3831.

48 See, recently, JOHAN VAN DER WALT, THE HORIZONTAL EFFECT REVOLUTION AND THE QUESTION OF SOVEREIGNTY 201 (2014).

49 Deutsche Telekom, C-50/96, EU:C:2000:72, para. 57.

${ }^{50}$ See, among others, Marzia Barbera, Eguaglianza e differenza nella nuova stagione del diritto antidiscriminatorio comunitario, 25 GIORN. DIR. LAV. REL. IND. 399 (2003). A clear example of this "double aim" is in the recent case Feryn, C-54/07, EU:C:2008:397 concerning the assessment of the directly discriminatory nature of an employer's public statements not to recruit any employees of a certain ethnic or racial origin. Here a direct discrimination is deemed to exist despite the fact that it appeared to be very difficult to identify individual victims, as persons from the named ethnic or racial origins, apparently largely discouraged by the statement, did not even apply for a position with that employer. By drawing back the threshold of protection against racial discrimination to the point in which there is not yet a victim, the ECJ places weight on the well-functioning of labour market and on effectiveness of freedom to access to the market. According to some scholar, this confirms the shift of the focus of the employment protection from the employment contract to the integration in the labour market (Marzia Barbera, Trasformazioni della figura del datore di lavoro e flessibilizzazione delle regole del diritto, in LA FIGURA DEL DATORE DI LAVORO. ARTICOLAZIONIE TRASFORMAZIONI. ATTI DEL CONVEGNO NAZIONALE A.I.D.L.A.S.S 46 (Giuffrè 2010). 
creation of equality bodies ${ }^{51}$ ) is completely ignored. Maybe, as we shall see, the essentially individual character of the principle and the fundamental role it plays in the functioning of the Single Market and in market integration can explain the extensive protection the Court of Justice confers on it. Symmetrically, that also explains the narrow protection the Court confers on other social fundamental principles, such as the right to information and consultation and the right to collective bargaining and collective action.

\section{CONSTITUTIONALIZATION OF COLLECTIVE EMPLOYMENT RIGHTS}

\section{A. The Right to Information and Consultation}

In Association de médiation sociale (hereinafter $A M S),{ }^{52}$ the Court of Justice did not follow the approach it had taken in Mangold and Kücükdeveci; rather, it denied direct horizontal effect to the information and consultation rights set forth in Article 27 of the Charter, the content of which had been given specific expression by a Directive. ${ }^{53}$.

As noted above, in Mangold and, more particularly, in Kücükdeveci, the Court held that a directive that transposed or was connected to a fundamental individual right (in those cases, the right to non-discrimination on the ground of age) could be used in private employment relationships and disputes. Thus, a national court could set aside national legislation if it found such legislation incompatible with EU law. In $A M S$, the question was whether the Mangold/Kücükdeveci holdings could also be invoked in connection with the transposition of Charter Article 27 by Article 1, Directive 2002/14/EC which provides the principle with "substantive and direct expression". 54

The Court's short answer was that Article 27 only defines a principle, (not a right) that does not have direct horizontal effect. It was, therefore, impossible to give Directive 2002/14/EC direct horizontal effect, as it was only connected to a principle that had no such direct horizontal effect. ${ }^{55}$ On the contrary, the Court had previously held that the principle of non-discrimination on grounds of age was "sufficient in itself to confer on individuals an individual right which they may invoke as such". 56

The Court's underlying reasoning for the distinction made between these two fundamental principles is not very convincing. As indicated above, the Kücükdeveci Court

\footnotetext{
${ }^{51}$ Equality bodies are independent organizations assisting the victims of discrimination.

52 Association de médiation Sociale, C-176/12, EU:C:2014:2.

53 Art. 1 of Directive 2002/14/EC of the European Parliament and of the Council of 11 March 2002 Establishing a General Framework for Informing and Consulting Employees in the European Community, 2002 OJ (L80),

${ }^{54}$ See AG Cruz Villalón Opinion, Association de médiation sociale, C-176/12, EU:C:2013:491, para. 65-66.

55 Association de médiation Sociale, para. $45 \mathrm{ff}$.

56 Association de médiation Sociale, C-176/12, EU:C:2014:2, para 46-49.
} 
seemed to think that non-discrimination on the ground of age was not a self-executing right, but was, rather, a principle given substantive content and expression by Directive 2000/78/EC, which, in turn, gave both the Court of Justice and national courts the ability to scrutinize national legislation for consistency with EU law. It is difficult to consider the principle of non-discrimination, found in Article 21.1 in Chapter 3 "Equality" of the Charter, a self-executing right. On the contrary, insofar as it is based on the values of human dignity and substantial equality ${ }^{57}$, that right appears to be a social positive right, defining the specific commitment of the States and institutions to fight and remove all the obstacles that impede achievement of "full equality in practice". ${ }^{8}$ In this respect, non-discrimination is a "bidirectional right" (like the bidirectional freedom to organize and right to strike), which combines both a negative freedom from State and institutional action and social positive duties on the State and institutions.

Through its AMS judgment, the Court introduced a highly-disputable distinction between fundamental rights and principles, affecting the role each can play in interpreting the acts of EU Institutions ${ }^{59}$; the limited, vertical effect of directives can only be overcome if the directive is connected to a fundamental right that itself has horizontal direct effect. However, the Court's reasoning presupposes, on the one hand, a clear distinction between such fundamental rights and principles. The distinction is not at all clear in the Charter, insofar as it is based either on (a) the idea that rights are recognized in the ECHR or in the common constitutional traditions of the Member States(principles, however, are not) or (b) on the continental European distinction made between fully enforceable rights and guiding or "programmatic" principles. ${ }^{60}$ On the other hand, the Court's reasoning inevitably leads to a devaluation - or a judicial "redrafting"61 — of Charter Article 52.5. Principles do not appear to have no legal effects, but, rather, they can be used by courts as a means of interpretation or "as a standard to review the legality of other acts of the EU or of Member States". 62

\footnotetext{
${ }^{57}$ See, among others, Erica Howards, The European Year of Equal Opportunities of All-2007: Is the EU Moving Away from a Formal Idea of Equality?, ELJ 2008, vol. 14, p. 168-185; Marzia Barbera, Eguaglianza e differenza, supra note 50.

58 See Article 7, Dir. 2000/78/EC.

59 See critically Silvana Sciarra, Association de médiation sociale. The disputed role of EU fundamental principles and the point of view of labour law, in SCRITTI IN ONORE DI GIUSEPPE TESAURO III, 2431 (Editoriale Scientifica 2014)

${ }^{60}$ See supra $§ 1$. See also Sacha Prechal \& Steve Peers, Comment on Article 52, in THE EU CHARTER OF Fundamental Rights 1455 (Steve Peers et al eds., 2014).

${ }^{61}$ See Pierre Rodière, L'information et la consultation des travailleurs dans la Charte des droits fondamentaux : un droit, un principe, finalement rien ?, SEMAINE SOCIALE LAMY, Feb. 2, 2014.

${ }^{62}$ Prechal \& Peers, supra note 60, at 1506.
} 
The minimal reasoning given by the Court should be distinguished from that of AG Cruz Villalón, which was much more elaborate. ${ }^{63}$ First, AG Cruz Villalón acknowledged that information and consultation rights were, in fact, merely "principles" within the meaning of Article 52 of the Charter. ${ }^{64}$ Relying on the continental European tradition, he further recognized that the distinction was rooted in the legal tradition of several Member States that regard social rights as programmatic principles or guidelines addressed to public institutions for their effective implementation and "invokability" 65 . Social rights, though they work as guidelines for interpretation, are not self-executing; rather, they are but positive rights, which are clearly addressed only to governments. ${ }^{66}$ As we will see, this reasoning cannot be invoked for all social rights protected by the Charter's Title IV-Solidarity-. For instance, according to several scholars, Article 28 (Right to collective bargaining and action) defines a fully justiciable right. ${ }^{67}$

AG Cruz Villalón went on to investigate the meaning of Article 52.5; he made a distinction between the "implementing acts of the principles" 68 that give specific expression to a particular principle (focusing, in particular, on directives), on one hand and the potential to invoke such principles or the justiciability of such principles in private disputes, on the other. With regard to the former, AG Cruz Villalón identified such implementing acts as "provisions which can be said to give specific substantive and direct expression to the content of the "principle"". 69 In the AG's opinion, Article 3(1) Dir. 2002/14/EC is a good example of just such an implementing act: it gives specific substantive and direct expression to the principle of workers' information and consultation.

That distinction led AG Cruz Villalón to investigate the latter, that is, the justiciability or invokability of such principles in private disputes. The core of his reasoning was that legislative acts - whether they be regulations or directives - that do not simply implement

\footnotetext{
63 AG Cruz Villalón Opinion, Association de médiation sociale, C-176/12, EU:C:2013:491. For a deep commentary of the opinion see See Sciarra, supra note 59; Bruno Caruso \& Veronica Papa, I percorsi "accidentati" della Carta dei diritti fondamentali dell'UE... eppur la talpa scava, RIVISTA GIURIDICA DEL LAVORO, Jan. 15, 2014, at 185; Rodière, supra note 61.

${ }^{64}$ AG Cruz Villalón Opinion, Association de médiation sociale, C-176/12, EU:C:2013:49.

65 AG Cruz Villalón Opinion, Association de médiation sociale, C-176/12, EU:C:2013:49, para. 66.

66 The AG also specifies that "That idea also reflects the concern within the Convention entrusted with drafting the Charter and within the Convention on the Future of Europe. Several Member States feared that the recognition of particular economic and social rights would result in the judicialisation of public policy, particularly in areas of significant budgetary importance. In fact, what would ultimately be called 'principles' were described in the initial drafts as "social principles"” (para. 49).

${ }^{67}$ See, among others, S. Prechal \& Peers, supra note 60, at 1508.

${ }^{68}$ AG Cruz Villalón Opinion, Association de médiation sociale, C-176/12, EU:C:2013:491, para. $62 \mathrm{ff}$.

${ }^{69}$ AG Cruz Villalón Opinion, Association de médiation sociale, C-176/12, EU:C:2013:491, para. 63.
} 
principles, but "give substantive and direct expression to the content of principles",70 become incorporated in the substance of the principle. Thus, they, themselves become criteria for assessing the validity and legality of other acts adopted by EU institutions or Member States implementing such principles pursuant to Article 52.5 of the Charter. By referring to Mangold and Kücükdeveci, AG Cruz Villalón highlighted that a principle could be used in private disputes, as the main tool of interpretation of acts of institutions and Member States, once it had been given substantive content and expression in a directive or in another legislative act. ${ }^{71}$ Otherwise, simply by choosing to implement a principle via a directive, which has no direct horizontal effect, "the legislature would be able to deprive individuals, in disputes inter privatos, of the judicial review of validity which the Charter (Article 52.5) guarantees them". 72

AG Cruz Villalón tried to take advantage of the opportunity to lay down a general legal theory explaining the innovative role the CFR (in particular, Title IV-Solidarity) could play in the interpretation and review of the legislative acts of the EU Institutions and Member States. ${ }^{73}$ His reasoning would appear to be fundamental in order to avoid the risk of depriving Charter Article 52.5 of any legal effect and, further, would appear consistent with the programmatic guidelines set forth in Mangold and Kücükdeveci.

However, by distinguishing "implementing acts of the principles" that give substantive content and expression to the principle and become incorporated therein from other legislative implementing acts that can be reviewed and interpreted in light of such content and expression pursuant to Article 52.5 of the Charter $^{74}$, AG Cruz Villalón seems to have become trapped in a vicious circle. ${ }^{75}$ Distinguishing between "acts giving specific substantive and direct expression to the content of a 'principle' and other acts, whether legislative acts or their individual implementing acts" ${ }^{, 76}$ appears to be a very difficult task. Nevertheless, AG Cruz Villalón's reasoning is of great value insofar as it tried to explain how fundamental socio-economic principles can become the legal standard of review for the legality of implementing acts of the institutions and Member States, as authorized by Charter Article 52.5. Unfortunately, AG Cruz Villalón's interpretative effort was undervalued and

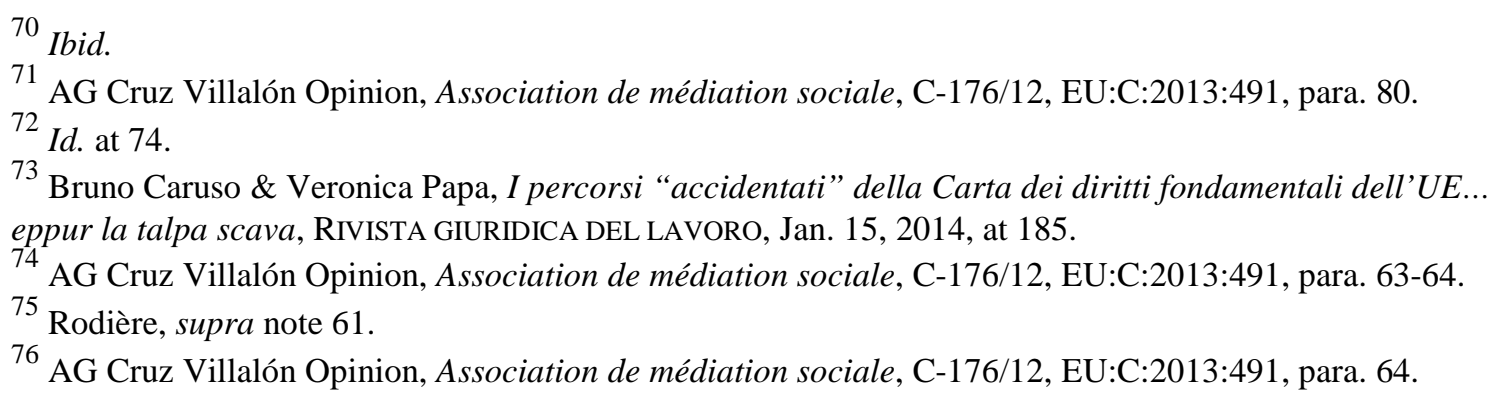


completely rejected by the Court of Justice, which resulted in depriving Charter Article 52.5 of any legal effect.

\section{B. Right of Collective Bargaining and Action}

The caution of the Court towards collective rights was made clear in connection with another fundamental right: the right of collective bargaining and action, as set for the in Charter Article 28. As noted above, unlike information and consultation rights, this right might be described as bidirectional, in the sense that it creates both negative and positive obligations for the Member State. ${ }^{77}$

The right to take collective action, including the right to strike, is defined by the Court of Justice as a "fundamental right which forms an integral part of the general principles of Community law the observance of which the Court ensures". ${ }^{78}$ Thus, the right should be considered directly enforceable and justiciable according to Charter Article 52.4. ${ }^{79}$ If the right of collective bargaining and action were not regarded as a right, it would be deprived of any effect in the EU legal context due to the limited competence of EU institutions in this particular field pursuant to Articles 153(f) and 154(2)(b) and (5) TFEU. ${ }^{80}$

Nonetheless, in spite of the institutions' limited competence, the Court of Justice has frequently inferred from Article 6 TEU, which equates provisions of the Charter to other Treaty provisions, a legal basis for courts, including the CJEU, to balance fundamental social rights with economic freedoms. Interestingly, in Viking, ${ }^{81}$ the Court of Justice held that the right to strike is subject to the proportionality test, going beyond the EU limited competence in the social field and highlighting the problem of the democratic deficits of the European Union. $^{82}$

\footnotetext{
${ }_{77}^{7}$ See, L. Mengoni, supra note 6; Baldassarre, supra note 6, at 175; Kenner, supra note 9, at 4.

78 The International Transport Workers' Federation and The Finnish Seamen's Union v. Viking Line, C-438/05, EU:C:2007:772, para. 44.

79 As said above (see supra $\S 1$ ), the right to strike and the right to collective bargaining are considered directly enforceable rights or "bidirectional" rights in the tradition of several Member States. For a comparative overview, see, among others, Martine Le Friant, Collective Autonomy: Hope or Danger?, COMP. LABOR LAW \& POL'Y J., 34 (2013) 627; Bob Hepple, The Right to Strike in an International Context, 15 CANADIAN LABOR \& EMPLOYMENT LAW J., 133.

${ }^{80}$ See, for this remark, Massimiliano Delfino, Limiti e prospettive della contrattazione collettiva europea nel diritto primario dell'Unione, in UNA NUOVA COSTITUZIONE PER IL SISTEMA DI RELAZIONI SINDACALI? 70 (Lorenzo Zoppoli et al. eds, 2014).

${ }^{81}$ The International Transport Workers' Federation and The Finnish Seamen's Union v. Viking Line, C-438/05, EU:C:2007:772.

${ }^{82}$ Maria V. Ballestrero, Europa dei mercati e promozione dei diritti, W.P. C.S.D.L.E. "Massimo D'Antona", no. 55/2007; Johan Van der Walt, supra note 48, chap. VII, where the Author strongly observes that in Viking, Laval, Rüffert there is an evidence of the Court of Justice as a Court which 'governs', by transferring sovereignty to the European Union without regard to divisive social concerns and majority-minority relations.
} 
The Court's reasoning was quite simple. Charter Article 28 acknowledges that workers have the right to take action, including strike action, to defend their interests "in accordance with Union law". The crucial question for the Court, then, was the meaning of that limitation? Did it that mean that restrictions on the exercise of the fundamental right must be provided for only by Union or national law and practices? Or did it mean that the exercise of the right to strike and collective bargaining must be reconciled with all the other EU provisions?

In Viking, the Court adopted the latter proposition; it further expanded that general limit by stating that the exercise of the right to strike

does not fall outside the scope of the provisions of the Treaty and must be reconciled with the requirements relating to rights (such as [the] right to establishment) protected under the Treaty and in accordance with the principle of proportionality. ${ }^{83}$

Collective action, then, became subject to double judicial scrutiny: first, it applied the legitimate aim test and then applied the proportionality test. By doing so, it established a rule/exception relationship between economic freedoms and collective rights. In that regard, the judicial balancing required by the Viking judgment leads to a "transfer of sovereignty to judiciary that takes over the functions of the government". 84

If, however, we adopt the first interpretation of the wording "in accordance with Union law" - that is, any restrictions on the exercise of this fundamental right must be provided for only by Union law or national law and practices - the outcome of the judicial balancing might change. This interpretation seems to be much more consistent also with Article 52 of the CFR.

In a nutshell, Charter Article 52.1 provides

Any limitation on the exercise of the rights and freedoms recognised by this Charter must be provided for by law and respect the essence of those rights and freedoms. Subject to the principle of proportionality, limitations may be made only if they are necessary and genuinely meet objectives of general interest recognised by the Union or the need to protect the rights and freedoms of others. (Emphasis added)

With regard to 'judicial activism' in Europe, see, recently, MARC DAWSON ET AL, JUDICIAL ACTIVISM AT THE EUROPEAN COURT OF JUSTICE (Marc Dawson et al. 2013).

${ }^{83}$ The International Transport Workers' Federation and The Finnish Seamen's Union v Viking Line, C-438/05, EU:C:2007:772, para. 46. On the contrary, with specific regard to collective bargaining, in the famous judgment Albany, C-67/96, EU:C:1999:430, para. 59 where the Court concludes that, although "certain in restrictions of competition are inherent in collective agreements", the social policy objectives pursued by collective agreements, allow them to fall outside EU competition law.

84 Johan Van der Walt, supra 48, at 335. 
Further, Charter Article 52.3 also that the essence of rights corresponding to rights guaranteed also by the European Convention of Human rights shall be at least the same, whilst "more extensive protection" is always possible. ECHR Article 11.2, for example, provides that the right to form and join a Trade Union cannot be subject to any restrictions

other than such as are prescribed by law and are necessary in a democratic society in the interests of national security or public safety, for the prevention of disorder or crime, for the protection of health or morals or for the protection of the rights and freedoms of others. ${ }^{85}$

According to the European Court of Human Rights, these restrictions have to be interpreted strictly. ${ }^{86}$

Finally, Charter Article 52.4 provides that fundamental rights that result from the constitutional traditions common to the Member States must be "interpreted in harmony with those traditions".

In light of that provision, it is very difficult to accept that the fundamental right of collective bargaining and action could be implicitly restricted by Treaty provisions that define the realm of economic freedoms. On the contrary, according to Charter Article 52, restrictions must be expressly imposed by Union or national law and must comply with the legitimate aim test and with proportionality test, without going below the standard of protection laid down in the ECHR.

In the meantime, Article 52 prevents looking at fundamental rights as mere restrictions on other fundamental freedoms. ${ }^{87}$ By inferring the limits of collective rights and the rule/exception relationship between economic freedoms and collective rights from the scope of Treaty provisions, the Court of Justice imposed precise goals and functions on collective action, thereby impairing the very essence of the right. A clear example thereof is provided in Laval. $^{88}$

\footnotetext{
85 This paragraph, as has been observed, does not adequately consider the nature of social rights, which do not simply prohibit any public interference, but, rather, prescribe social policy goals of state and institutions' actions in the social policy field. See Dieter Grimm, Il significato della stesura di un catalogo europeo dei diritti fondamentali nell'ottica della critica dell'ipotesi di una Costituzione europea, in DIRITTI E COSTITUZIONE NELL'UNIONE EUROPEA 11 (G. Zagrebelsky ed., 2003).

${ }^{86}$ See the recent judgment of the ECtHR, Demir and Baykara v. Turkey, Appl. No. 34503/97, November 12, 2008 , para. 97.

87 AG Cruz Villalón Opinion, Dos Santos Palhota and Others, C-515/08, EU:C:2010:245. Here the AG makes it clear that after constitutionalization of certain employment rights (such as right to fair and just working conditions, Article 31), it is not anymore possible to regard limitations of fundamental freedoms based on employment conditions or other collective rights in 'term' of restrictions, strictly interpreted (para. 53). "In so far as the protection of workers is a matter which warrants protection under the Treaties themselves, it is not a simple derogation from a freedom, still less an unwritten exception inferred from case-law" (para. 53).

${ }^{88}$ Laval un Partneri, C-341/05, EU:C:2007:809.
} 
Unlike in Viking, in the Laval case, the interference with the fundamental right to take collective action with the economic freedom to provide services was considered in a context of partial harmonization: the posting of workers regulated by Dir. 96/71/EC. It is not possible in this short work to analyze the complex Laval judgment in detail; suffice it to note that is has been criticized by a number of scholars. ${ }^{89}$ However, the core of the decision lies in the Court's finding that Article 3 of the Directive sets down a harmonized maximum standard of employment protection that the host Member State can impose on foreign service providers posting workers. As a result, collective action intended to improve working conditions beyond the maximum level set down in Article 3 - notably, collective action intended to force a foreign services provider to enter into a collective agreement, which has not erga omnes effects, providing for a minimum hourly wage ${ }^{90}$ - cannot be considered to be a "justified restriction" of the freedom to provide services.

Although it found that fighting social dumping and protecting workers' interests are an overriding reason of public interest ... which, in principle, justifies a restriction of one of the fundamental freedoms guaranteed by the Treaty", 91

it went on to find, in the context of posting of workers that the partial harmonization achieved by Directive 96/71/EC had already identified the maximum standard of employment protection that the host Member state can impose on foreign service providers. Thus, it held that an employer established in one Member State could only be required to observe, in another Member State, that level of protection set down in Article 3 of that directive. As in Sweden the wage levels is not set forth in law or collective agreements with erga omnes effects - as required by Article 3 - the Court held that they fell outside the field of application of Article 3 and, therefore, could not be imposed on foreign service providers.

\footnotetext{
${ }^{89}$ See, among the others, Simon Deakin, Regulatory Competition in Europe after Laval, Centre for Business Research, University of Cambridge Working Paper No. 364, 2008; Maria V. Ballestrero, supra note 82; Catherine Barnard, A proportionate Response to Proportionality, 37 EUR. L. REV. 117 (2012); F. Hendricks, The Role of the Judge in Labour Law and Employment Relations. Should Theory Save Proportionality Test?, Discussion Paper for the LLRN conference, Barcelona, 14 June 2013 and, recently, Johan Van der Walt, supra 48; GIOVANNi ORLANDINI, MERCATO UNICO DEI SERVIZI E TUTELA DEL LAVORO, (Franco Angeli,ed., 2013.

${ }^{90}$ Notably, Swedish Trade Unions have started collective actions - such as boycott - against a company incorporated under Latvian law (Laval) that temporarily posted its workers to work in Sweden in a building site and refused to enter into a collective agreement with Swedish Trade Unions as to guarantee to workers the Swedish level of hourly wage, which was definitely higher than the Latvian one. However, Swedish collective agreements are deprived of universal applicability and, therefore, they fall outside the realm of Article 3 of Dir. 96/71/EC that sets down employment conditions that should be applied to workers posted in the territory of a Member State, whatever is the law applicable to their employment relationship (namely, the law of the Country of origin).

${ }^{91}$ Laval un Partneri, C-341/05, EU:C:2007:809, para. 103.
} 
Interestingly, the principle of favor, which is recognized in Article $3(7)^{92}$ and which should guarantee that partial harmonization does not prevent regulatory competition above the minimum floor of rights set forth in the Directive, is denied any role. ${ }^{93}$ As Simon Deakin observed, "Laval gives the Posting of Workers Directive a 'pre-emptive' effect, reading it, contrary to its own clearly expressed intent, as if it were a ceiling not a floor". 94 As a consequence of Laval, collective autonomy is deprived of both one of its main goals, which is to improve existing living and working conditions ${ }^{95}$, and the ability to contribute to the construction of the social dimension of the EU market. To put it in another way, the right of collective bargaining and action is deprived of its very substance, contrary to Charter Article 52.1 .

One explanation for the controversial approach taken by the Court lies in contradictory EU views of "social dumping". Although the Court of Justice did not deny that "fighting social dumping" is an overriding reason of public interest, ${ }^{96}$ its main focus was on the creation of a Single Market and, consequently, on the effectiveness of the economic freedoms provided by the Treaties, regardless the manner in which those freedoms are exercised, including social dumping. ${ }^{97}$ In other words, social dumping has become, in reality, the most basic and most frequently used legitimate tool to achieve the Single Market, which deeply, and inevitably, undermines the substance and nature of collective rights.

There are few judgments in which the Court (or the Advocate General, for that matter) appears to be sensitive to the substance of collective rights. For instance, in Prigge, ${ }^{98}$ AG Cruz Villalón drew a distinction between national law which must originate from public

\footnotetext{
92 Article 3(7) provides that the paragraphs of Article 3 'shall not prevent the application of terms and conditions of employment which are more favourable to workers'.

93 It is worth noting that, in a recent judgment, the ECJ stated that more favourable provisions to workers fall outside the scope of the Directive. See Julian Hernández and Others, C-198/13, EU:C:2014:2055, para. 45. 94 Deakin, quoted above nt. 64, p. 22.

95 In this respect, it is worth considering the decision of the European Committee of Social Rights, pub. February 5, 2014, Swedish Trade Unions Confederation and Swedish Confederation of Professional Employees v. Sweden (appl. No. 85/2012). With regard to the so called Lex Laval, the European Committee of Social Rights holds that Trade Unions must be allowed to "strive for the improvement of existing living and working conditions of workers, and its scope should not be limited by legislation to the attainment of minimum conditions" (para. 120).

96 Laval un Partneri, C-341/05, EU:C:2007:809, para. 101.

$97 \mathrm{See}$, in this perspective, the boundaries between abuse of right in EU law and fraus legi drawn by the ECJ in several judgments. See, with regard to freedom of establishment of companies, among others, Centros, C212/97, EU:C:1999:126; Überseering, C-208/00, EU:C:2002:632; Cadbury Schweppes, C-196/04, EU:C:2006:544; Halifax and Others, C-255/02, EU:C:2006:121; VALE Építési, C-378/10, EU:C:2012:440; SICES and Others, C-155/13, EU:C:2014:145. Generally, see MARCO GESTRI, ABUSO DEL DIRITTO E FRODE ALLA LEGGE NELL'ORDINAMENTO COMUNITARIO (Giuffrè 2003).

98 Prigge and Others, C-447/09, EU:C:2011:573.
} 
authorities, and autonomy in collective bargaining, which enjoys a "special respect in national legal traditions". 99

By taking into consideration the list of legitimate reasons, set down in Article 6(1) Dir. 2000/78/EC, that can justify a derogation from the prohibition of age discrimination, AG Cruz Villalón concluded that the protection or preservation of collective autonomy can assume the nature of a legitimate social policy objective within the meaning of the Directive capable on occasion of reducing the scope of the general principle of non-discrimination on grounds of age. ${ }^{100}$

That is to say, he found it was not necessary to investigate the reasons behind a collective agreement that derogated from the prohibition of age discrimination (i.e., the automatic termination of pilots at the age of 60 at issue in the case). Rather, he found the need to preserve the autonomy of collective bargaining, in and of itself, to be a legitimate interest of social policy that could justify such a derogation. However, the Court of Justice did not follow this line of thought.

AG Cruz Villalón's approach might be aligned, to some extent, to the one taken by the Court in Schmidberger, ${ }^{101}$ which dealt with the freedom of assembly and association in relation to the Austrian Government's failure to ban an environmental demonstration on the Brenner motorway, which obstructed free movement of goods for almost 30 hours. The Court noted that the freedom of assembly and association "form[s] an integral part of the general principles of law the observance of which the Court ensures". ${ }^{102}$ It went on to hold that fundamental rights, though not absolute, may constitute a legitimate restriction of fundamental freedoms. Whether the ultimate restriction on such freedoms is, in fact, proportionate in relation to the legitimate aim pursued was left to national authorities, to be determined according to the criteria laid down by the Court of Justice. Essentially, the Court held that national authorities must weigh the values at stake and all of the circumstances to determine whether the legitimate aim could have been achieved with less restrictive measures. In Schmidberger, the decisive point was that the fundamental rights of freedom of assembly and expression, in and of themselves, were considered the legitimate aim of the government's action, while the actual purpose of the demonstration (i.e., protection of

\footnotetext{
99 AG Cruz Villalón Opinion, Prigge and Others, C-447/09, EU:C:2011:321.

${ }^{100}$ AG Cruz Villalón Opinion, Prigge and Others, C-447/09, EU:C:2011:321, para. 82.

101 Schmidberger, C-112/00, EU:C:2003:333.

102 Id., para. 71.
} 
environment and public health) played no formal role in determining legitimacy. ${ }^{103} \mathrm{AG}$ Jacobs underscored that

although protection of health and the environment in the Alpine region is clearly a major concern, the issue to be decided here is not a direct conflict between that concern and the free movement of goods. In my view, the aim of the demonstration is of no significance when assessing the possible liability of the Member State. ${ }^{104}$

This approach appears to be much more sensitive and respectful towards the very substance and nature of collective rights.

\section{CONCLUSION}

My main aim here was a critical appraisal of the "constitutionalization" of socioeconomic rights at the EU level. Specifically, I have pointed out the different approaches taken by the Court of Justice toward individual socio-economic rights, on the one hand, and collective socio-economic rights, on the other.

In its judgments concerning non-discrimination and equal treatment, the Court of Justice strongly supported non-discrimination rights and their direct horizontal effect, which effect it found could be extended to Directives that transpose the content of such rights. A plausible explanation for the Court's approach might be that non-discrimination rights are predominantly understood as individual rights that can be more easily reconciled with the main character of EU law and EU community, based on the empowerment of the individual and of the EU citizen, ${ }^{105}$ rather than of the people of Europe and of intermediate groups. The collective aspect of non-discrimination rights, though certainly existent, has not yet been explored or taken into account by the Court. Moreover, as mentioned above, nondiscrimination is and has always been the most basic and essential tool used to achieve the Single Market.

To date, the Court's attitude towards collective socio-economic rights - such as information and consultation rights and the right of collective bargaining and action - has been rather different. More precisely, the Court has focused on the controversial distinction

\footnotetext{
103 See, critically, Géraldine Gonzales, EC Fundamental Freedoms v. Human Rights in the Case 112/00 Eugen Schmidberger v. Austria [2003] ECR I-5659, 31 LEGAL ISS. ECON. INTEGR. (2004) at 219 where the A. underlines that, contrary to the ECJ's legal reasoning, the aim of the demonstration should be 'regarded as an important factor to determine State liability'. In effect, substantially, the relevance of values such as environment and public health seem to influence, to some extent, the legal reasoning of the Court and justify the wide margin of discretion conferred to National authorities (see, for instance, para. 66 of the judgment).

104 AG Jacobs Opinion, Schmidberger, C-112/00, EU:C:2002:437.

105 Mark Dawson, The political face of judicial activism: Europe's law-politics imbalance, in JUDICIAL ACTIVISM AT THE EUROPEAN COURT OF JUSTICE 29 (Mark Dawson et al. eds., 2013).
} 
between "rights" and "principles" and has used it to deny any direct horizontal effect of collective rights. It has even gone so far as to demote the role collective rights and "solidarity" play when evaluating the compatibility of that acts of institutions and Member States with EU law. Furthermore, the weight the Court has given to the Single Market, whatever the reasons underlying the exercise of economic freedoms (e.g., social or fiscal dumping), has undermined the very substance of collective rights, the purpose of which is to fight social dumping and to improve working conditions.

In the face of such Court decisions, what, if any, is the future of labor law and of socioeconomic rights? I have not tried to address that very broad and complex question here. Nevertheless, I suggest that a different scenario be considered, one that endorses a different interpretation of the Charter, particularly its Articles 28 and 52. A different interpretation could very well lead to a much more critical assessment of the Court's use of judicial balancing when reviewing the application of the legitimate aim and proportionality tests to collective labor rights. In turn, it might be the key to opening a more critical appraisal of both the rule/exception relationship between economic freedoms and collective socio-economic rights and between the economic and social dimension of the European Union. 